\title{
Placebo effect of saline in pain management: compared study with hemodialysis and non-hemodialysis nurses' experiences
}

\author{
Ağr yönetiminde salin uygulamasının plasebo etkisi: Hemodiyalizde ve \\ diğer birimlerde çalışan hemşirelerin deneyimlerinin karşılaşttrılması
}

\author{
Seher ÜNVER, ${ }^{1}$ Meltem YILDIRIM, ${ }^{2}$ Emine ÜNAL ${ }^{3}$
}

\begin{abstract}
or
Summary

Objectives: To identify and compare hemodialysis and non-hemodialysis nurses' experiences about the placebo effect of intravenous saline injection in pain management.

Methods: This descriptive study design was carried out between January 22nd - February 4th, 2012 with 202 voluntary nurses who work in hemodialysis and medical-surgical clinics. An online survey system was used for data collecting. Cookie and IP logging prevented multiple voting. The survey contained 21 questions. Data were evaluated by descriptive statistics and Chi-Square test.

Results: The mean age of the nurses was $31.13 \pm 6.03$ years. Fifty-two point five percent $(n=106)$ of the nurses were working in a hemodialysis unit while the others (45.5\%) were from other clinics such as medical and surgical units. While $68.4 \%$ of the hemodialysis nurses stated that they "sometimes" use placebo, $62.7 \%$ of the non-hemodialysis nurses stated that they "rarely" use placebo. In hemodialysis nurses, "always" believing the patient's pain was significantly lower than expected count. This ratio was found more than expected in non-hemodialysis nurses $(\mathrm{p}=0.006)$. Hemodialysis nurses stated that "the use of placebo is not necessary to be recorded". However, non-hemodialysis nurses stated more than expected that "the placebo usage should be recorded" ( $\mathrm{p}=0.006)$.

Conclusion: Hemodialysis nurses are more likely to use saline injection as a placebo in pain management rather than nonhemodialysis nurses. However, non-hemodialysis nurses believe the patient's pain more than hemodialysis nurses do. This makes placebo usage for the first step choice among hemodialysis nurses.
\end{abstract}

Key words: Hemodialysis; nurse; pain management; placebo.

\section{Özet}

Amaç: Ağr yönetiminde intravenöz salin uygulamasının plasebo etkisi konusunda, bemodiyalizde ve diğer alanlarda çalışan bemşirelerin deneyimlerini tanımlamak ve karşılaştırmak.

Gereç ve Yöntem: Bu tanımlayııı çalışma, 22 Ocak - 4 Şubat 2012 taribleri arasında, hemodiyalizde ve tıbbi-cerrabi kliniklerinde çalşan 202 gönüllü bemşire üzerinde yürütüldü. Veri toplamada online anket sistemi kullanıldı. Cookie ve IP günlü̈̆̈̈ kullanılarak, çoklu anket doldurulması engellendi. Ankette 21 soru mevcuttu. Veri değerlendirilmesinde tanımlayıcı istatistik ve ki-kare kullanıld. Bulgular: Hemşirelerin yaş ortalaması $31.13 \pm 6.03$ idi. Hemşirelerinin \%52.5'i $(n=106)$ bemodiyalizde çalışırken diğerleri (\%45.5) dabili ve cerrabi birimlerde çalışıordu. Hemodiyaliz bemşirelerinin \%68.4'ü (n:52) plaseboyu "bazen" kullanırken, diğer birimlerdeki bemşirelerin \%62.7'si $(n=32)$ "çok nadir" kullanmaktayd. Hemodiyaliz hemşireleri arasında hastanın ağrısı olduğuna "her zaman" inananların sayısı beklenen değerden daha azdı. Bu değer diğer birimlerdeki bemşirelerde beklenenden daba fazlaydı $(p=0.006)$. Hemodiyaliz hemşireleri "plasebo kullanımının kayıt edilmesine gerek olmadığını" belirtmekteyken, bemodiyaliz hemşiresi olmayanlar beklenenden daba yüksek değerde "plasebo kullanımının kayıt edilmesi gerektiğini” belirtti $(p=0.006)$.

Sonuç: Hemodiyaliz hemşireleri, ağr yönetiminde plaseboyu diğer alanlarda çalışan bemşirelere göre daha fazla kullanmaktadır. Ancak hemodiyaliz dışında çalı̧an hemşireler, hastanın ağrısının olduğuna bemodiyaliz hemşirelerinden daba çok inanmaktadır. Bu durum ağrı yönetiminde plasebo kullanımını, bemodiyaliz hemşireleri arasında birincil tercib yapmaktadır.

Anahtar sözcükler: Hemodiyaliz; hemşire; ağrı yönetimi; plasebo.

'FMC Bursa Dialysis Center, Bursa;

${ }^{2}$ Halic University School of Nursing, Istanbul;

${ }^{3}$ Department of Manager of Nursing Services, Fresenius Medical Care, Istanbul

'Bursa FMC Diyaliz Merkezi, Bursa; ${ }^{2}$ Haliç Üniversitesi, Istanbul;

${ }^{3}$ Fresenius Diyaliz Hizmetleri, Hemşirelik Hizmetleri Departmanı, İstanbul

Submitted (Başvuru tarihi) 15.07.2012 Accepted after revision (Düzeltme sonrası kabul tarihi) 02.10.2012

Correspondence (illetişim): Seher Ünver, BSN, MSc. İstanbul Üniversitesi, Florence Nightingale Hemşirelik Fakültesi,

Abide-i Hürriyet Caddesi, 34381 Şişli, İstanbul, Turkey.

Tel: +90 - 212 - 4400000 e-mail (e-posta): seher.unver@hotmail.com
Şimdiki kurumları:

'Department of Surgical Nursing, İstanbul University, Faculty of Health Sciences, Istanbul;

2Department of Nursing and Health Services, Yeditepe University, Faculty of Health Sciences, Istanbul

'Iistanbul Üniversitesi, Sağlık Bilimleri Enstitüsü, Cerrahi Hastalıkları Hemşireliği Anabilim Dalı, İstanbul;

${ }^{2}$ Yeditepe Üniversitesi, Sağlık Bilimleri Fakültesi,

Hemşirelikte Sağlık Hizmetleri Bölümü, istanbul 


\section{Introduction}

Pain is a personal, subjective and emotional experience influenced by cultural learning. It is also the meaning of the situation, attention, and other psychological variables. ${ }^{[1]}$ However, the best definition of pain is provided by The International Association for the Study of Pain: "Pain is an unpleasant sensory and emotional experience associated with actual or potential tissue damage, or described in terms of such damage." ${ }^{[2]}$

In recent years, great advances are made in understanding the mechanisms that underlie pain and in its treatment. The roles of factors that are out of the patient's body have been clarified ${ }^{[3]}$ and the value of a team approach in pain management is received a greater recognition. According to an Institute of Medicine report, the complexity of healthcare increasingly requires that healthcare professionals collaborate effectively in interdisciplinary teams to ensure the effectiveness and reliability of care. ${ }^{[4]}$

In the late eighteenth and early nineteenth centuries, placebo was a term that was used for a type of treatment that doctors gave to please a patient. The word placebo itself originated from Latin for "I will please" ${ }^{[5]}$ and its effect is the positive psychosomatic response of an individual to a treatment. Placebo is a powerful tool for pain control in susceptible persons. ${ }^{[6,7]}$ In the typical paradigm used to produce placebo analgesia, a substance known to be non-analgesic (e.g., saline solution) is administered, and it is told as a powerful painkiller. ${ }^{[8]}$ The American Society for Pain Management Nurses (ASPMN) agrees that placebo use is fraudulent and deceptive when used to assess and treat pain, but they support placebo use in clinical trials in which the patient has signed an informed consent and the institutional review board has approved the research. ${ }^{[9]}$

An analgesic treatment activates the endogenous opioid systems and administration of a placebo painkilling therapy together with the appropriate verbal instructions (such as "your pain is going to decrease") provides a pain reduction via the opioid receptors. Levine et al. (1978) found that placebo analgesia is mediated by endogenous opioids and in another study (1981) they found that a hidden injection of a 6-8 $\mathrm{mg}$ morphine corresponds to an open injection of saline solution in full view of the patient. This means, injecting a saline solution while telling the patient that a painkiller is as potent as 6-8 mg of morphine. ${ }^{[5,10]}$

The use of placebos for pain management outside of a clinical trial involves not believing the patient's report of pain and illustrates the ineffectiveness of a healthcare team. Recently, there has been more systematic review of the nature of the placebo response in clinical trials and in practice. ${ }^{[2]}$ For over 500 Danish physicians who responded to a questionnaire, placebo use was as high as $86 \%$ among general practitioners, 54\% among hospital-based physicians, and $41 \%$ of private specialists. ${ }^{[1]}$ In Chicago, $45 \%$ of 231 internists affiliated with three local medical schools admitted to using the placebo. ${ }^{[12]}$ In another study in Israel, they questioned 90 physicians and nurses in primary and tertiary care and found that $60 \%$ used the placebo. ${ }^{[13]}$

Hemodialysis nurses develop a close relationship with patients as dialysis treatment is typically required three days a week and they mostly know about the patients' physical situations. This may affect their approach to pain management. Because there has been no significant research on placebo use by hemodialysis nurses and different clinic nurses in the literature, we developed a study to identify and compare hemodialysis and non-hemodialysis nurses' experiences about the placebo effect of intravenous saline injection in pain management.

\section{Materials and Methods}

\section{Design, setting and participants}

This descriptive study design was carried out between January 22nd and February 4th in 2012 with 202 voluntary nurses who work in hemodialysis and medical-surgical clinics.

\section{Data collection}

The nurses who were a member of a social networking website were informed about the aim of the study and were asked to participate. An online survey system was used for data collecting. The survey contained 21 questions. Demographic information was collected for descriptive purposes. Yes/No ques- 
tions were asked about the participant's knowledge, usage, and overall interest in intravenous saline injections. Multiple-choice questions were focused on clinical practice experiences with saline injections. Other questions were about their experiences regarding pain relief level and experiences with the administration of saline injections used in their clinics.

\section{Statistical analysis}

The data were evaluated by descriptive statistics and Chi-Square test. The results were evaluated with $\mathrm{p}<.05$ significance level and $95 \%$ reliability interval.

\section{Ethical aspects of the study}

Not to take the nurses' time with papers of surveys while they're on duty; the participants were asked to participate in the study by an online survey system. Cookie and IP logging prevented multiple voting. Any ethical permission is taken but institutional permission is taken from the dialysis centers to do this investigation of plasebo usage.

\section{Results}

The mean age of the nurses was $31.13 \pm 6.03$ and the average working period of time was $9.33 \pm 6.39$ years. Forty-seven point five percent $(\mathrm{n}=96)$ of the nurses were BSN graduate. Among BSNs; 39.6\% ( $\mathrm{n}=38)$ were hemodialysis nurses. Fifty-two point five percent $(\mathrm{n}=106)$ of the nurses were working in a hemodialysis unit while the others $(45.5 \%, \mathrm{n}=94)$ were from other clinics such as medical and surgical units.

\section{The use of placebo}

Eighty-one point two percent $(n=164)$ of all the nurses stated that they had used placebo for pain management at least once in their clinical experience; while $18.8 \%(n=38)$ had never used placebo for pain management. In hemodialysis nurses $86 \%$ $(n=94)$ had used placebo at least once in their clinical experience. This ratio was found $77.9 \%(\mathrm{n}=70)$ in non-hemodialysis nurses.

\section{Believing the patient's pain among nurses} In hemodialysis nurses; "always" believing the patient's pain were significantly lower than expected count. This count was found more than expected in non-hemodialysis nurses $(\mathrm{p}<.01)$ (Table 1).

\section{Frequency of placebo use}

From the nurses who used placebo; $68.4 \%(n=52)$ of the hemodialysis nurses stated that they "sometimes" use placebo, while $62.7 \%(n=32)$ of the nonhemodialysis nurses stated that they "rarely" use placebo. Fifty-seven point three percent $(n=51)$ of the hemodialysis nurses stated that more than half of their patients' pain relieve with saline injection. This ratio was $42.7 \%(n=38)$ in non-hemodialysis nurses. The number of nurses who "mostly" and "sometimes" use placebo for pain management were found significantly more than expected in hemodialysis nurses group $(\mathrm{p}<.001)$ (Table 2$)$.

\section{Placebo exposure time}

Hemodialysis nurses stated that the pain relieved in $86.2 \%(n=81)$ of the patients with placebo in 30 minutes and this count was found more than expected $(\mathrm{p}<.05)$. In non-hemodialysis nurses this count was $68.6 \%(n=48)$.

\section{Preferring placebo in pain management}

The number of nurses who preferred placebo for the

Table 1. Comparison between memodialysis and non-hemodialysis nurses on believing the patient's pain

\begin{tabular}{lccccc}
\hline $\begin{array}{l}\text { Do you always believe } \\
\text { the patient's pain? }\end{array}$ & $\begin{array}{c}\text { Hemodialysis nurses } \\
\text { (n=106) }\end{array}$ & & \multicolumn{2}{c}{$\begin{array}{c}\text { Non-hemodialysis nurses } \\
\text { (n=96) }\end{array}$} \\
\cline { 2 - 3 } \cline { 5 - 6 } & $\mathbf{n}$ & $\%$ & & & \\
\hline Yes, always & 38 & 35.8 & & 53 & 55.2 \\
Expected count & 47.8 & & & 43.2 & \\
No, not always & 68 & 64.2 & & 43 & 44.8 \\
Expected count & 58.2 & & & 52.8 & \\
& & Chi-Square=7.627 & $\mathrm{p}=0.006$ & \\
\hline
\end{tabular}


Table 2. Comparison between hemodialysis and non-hemodialysis nurses on frequency of using placebo in pain management

\begin{tabular}{|c|c|c|c|c|c|}
\hline \multirow[t]{2}{*}{$\begin{array}{l}\text { How often do you use placebo } \\
\text { for pain management? }\end{array}$} & \multicolumn{2}{|c|}{$\begin{array}{l}\text { Hemodialysis nurses } \\
\qquad(n=106)\end{array}$} & \multicolumn{3}{|c|}{$\begin{array}{l}\text { Non-hemodialysis nurses } \\
\qquad(\mathrm{n}=96)\end{array}$} \\
\hline & $\mathbf{n}$ & $\%$ & & $\mathbf{n}$ & $\%$ \\
\hline Mostly & 23 & 21.7 & & 14 & 14.6 \\
\hline Expected count & 19.4 & & & 17.6 & \\
\hline Sometimes & 52 & 49.1 & & 24 & 25.0 \\
\hline Expected count & 39.9 & & & 36.1 & \\
\hline Rarely & 19 & 17.9 & & 32 & 33.3 \\
\hline Expected count & 26.8 & & & 24.2 & \\
\hline Never & 12 & 11.3 & & 26 & 27.1 \\
\hline \multirow[t]{2}{*}{ Expected count } & 19.9 & & & 18.1 & \\
\hline & & Chi-Squ & 0.532 & $p=0.000$ & \\
\hline
\end{tabular}

first-step in pain management in certain patients was significantly more than expected count in hemodialysis nurses $(\mathrm{p}<.001)$ (Table 3).

\section{Information given to patient}

Hemodialysis nurses who stated that they had never prepared the saline in front of their patients were lower than expected count while non-hemodialysis nurses who stated the same were found more than expected count. Eighty-six point six percent $(n=142)$ of all the nurses stated that if the patient asked the name of the medication given, they "sometimes" told the short name of Serum Physiologic (SF, in Turkish). Seventy-two percent $(n=118)$ of all the nurses stated that they preferred to use a different medication name instead of saying "SF". Although it was not a statistically significant finding; using a different medication name was more than expected count in hemodialysis nurses ( $\mathrm{p}>.05$ ).

Pain conditions that nurses prefer to use placebo Headache was the most common painful condition with $60.9 \%(\mathrm{n}=123)$. The other painful conditions were muscle pain with $29.7 \%(n=60)$, joint pain with $23.3 \%(\mathrm{n}=47)$, painful arm with $21.8 \%$ $(\mathrm{n}=44)$, abdominal pain with $21.3 \%(\mathrm{n}=43)$, lumbago with $12.4 \%(\mathrm{n}=25)$, back pain with $11.9 \%$ $(\mathrm{n}=24)$, kidney pain with $10.4 \%(\mathrm{n}=21)$, shoulder pain with $8.9 \%(\mathrm{n}=18)$, stomach ache with $7.4 \%$ $(\mathrm{n}=15)$, chest pain with $3.5 \%(\mathrm{n}=7)$ and tooth pain with 3\% $(n=6)$. Using saline injection for headaches $(\mathrm{p}<.001)$, muscle pains $(\mathrm{p}<.05)$ and painful arms $(\mathrm{p}<.01)$ were found more than expected count in hemodialysis nurses (Table 4).

Table 3. Comparison between hemodialysis and non-memodialysis nurses on using Placebo for the first step in pain management

\begin{tabular}{|c|c|c|c|c|c|}
\hline \multirow[t]{2}{*}{$\begin{array}{l}\text { Do you use placebo for the first } \\
\text { step of the pain management? }\end{array}$} & \multicolumn{2}{|c|}{$\begin{array}{l}\text { Hemodialysis nurses } \\
\qquad(n=106)\end{array}$} & \multicolumn{3}{|c|}{$\begin{array}{l}\text { Non-hemodialysis nurses } \\
\qquad(n=96)\end{array}$} \\
\hline & $\mathbf{n}$ & $\%$ & & $\mathbf{n}$ & $\%$ \\
\hline Yes, always & 72 & 76.6 & & 31 & 44.3 \\
\hline Expected count & 59.0 & & & 44.0 & \\
\hline No, not always & 22 & 23.4 & & 39 & 70.0 \\
\hline \multirow[t]{2}{*}{ Expected count } & 35.0 & & & 70.0 & \\
\hline & & Chi-Squ & .930 & $p=0.000$ & \\
\hline
\end{tabular}


Table 4. Comparison between hemodialysis and non-hemodialysis nurses on frequency of using placebo for certain painful conditions

\begin{tabular}{|c|c|c|c|c|}
\hline \multirow[t]{2}{*}{ Do you use placebo for ... } & \multicolumn{2}{|c|}{$\begin{array}{l}\text { Hemodialysis nurses } \\
\qquad(n=106)\end{array}$} & \multicolumn{2}{|c|}{$\begin{array}{l}\text { Non-hemodialysis nurses } \\
\qquad(\mathrm{n}=96)\end{array}$} \\
\hline & $\mathbf{n}$ & $\%$ & $\mathbf{n}$ & $\%$ \\
\hline \multicolumn{5}{|l|}{ Headaches } \\
\hline Yes & 79 & 74.5 & 44 & 45.8 \\
\hline Expected count & 64.5 & & 58.5 & \\
\hline No & 27 & 25.5 & 52 & 54.2 \\
\hline \multirow[t]{2}{*}{ Expected count } & 41.5 & & 37.5 & \\
\hline & & \multicolumn{3}{|c|}{ Chi-Square $=17.418 \quad p=0.000$} \\
\hline \multicolumn{5}{|l|}{ Muscle Pains } \\
\hline Yes & 39 & 36.8 & 21 & 21.9 \\
\hline Expected count & 31.5 & & 28.5 & \\
\hline No & 67 & 63.2 & 75 & 78.1 \\
\hline \multirow[t]{2}{*}{ Expected count } & 74.5 & & 67.5 & \\
\hline & \multicolumn{4}{|c|}{ Chi-Square $=5.369 \quad \mathrm{p}=0.020$} \\
\hline \multicolumn{5}{|l|}{ Painful Arms } \\
\hline Yes & 33 & 31.1 & 11 & 11.5 \\
\hline Expected count & 23.1 & & 20.9 & \\
\hline No & 73 & 68.9 & 85 & 88.5 \\
\hline \multirow[t]{2}{*}{ Expected count } & 82.9 & & 75.1 & \\
\hline & \multicolumn{4}{|c|}{ Chi-Square $=11.444 \quad p=0.001$} \\
\hline
\end{tabular}

\section{Discussion}

This is the first study examining hemodialysis nurses' use of placebo in clinical practice in the literature. Previous survey studies of hospital-based physicians or nurses showed that between 10 and $80 \%$ of respondents had used placebos in clinical practice. $^{[14-17]}$ Goodwin et al. (1979) found that forty-seven percent of the doctors had ordered and 32 of the nurses administered at least one placebo medication for pain relief. ${ }^{[7]}$ A recent survey which was conducted with 62 doctors and 31 head nurses who work in ambulatory care and hospitals in Israel found that $60 \%$ used placebo in their practice. ${ }^{[13]}$ In another study, to determine knowledge and patterns of placebo use, researchers sent surveys to house officers and registered nurses (RNs) working in two university teaching hospitals in the U.S. Seventyeight percent of physicians who responded had ordered at least one placebo as a painkiller, while $82 \%$ of RNs had administered at least one placebo as a painkiller. ${ }^{[7]}$ In Canada, researchers surveyed doc- tors and nurses from the Victoria General Hospital in Halifax to assess their knowledge and attitudes towards placebo, as well as their patterns of placebo use eighty percent of both the RNs and physicians reported having administered a placebo during their shift, with $91 \%$ of the placebos consisting of saline injections. ${ }^{[16]}$ In this study; it was found that placebo usage was $86 \%$ among hemodialysis nurses and $77.9 \%$ among non-hemodialysis nurses.

In a study, when medical and nursing staff were asked to rate their patients' pain intensities, they rated the pain lower than the patients did. ${ }^{[18]}$ Nurses do not always believe what patients tell them about their pain. Although nurses claim to listen to what patients tell them about their pain, they may be influenced by their own beliefs and attitudes when it comes to accepting the patients' reports of pain. ${ }^{[19]}$ In this study; $35.8 \%$ of the hemodialysis nurses stated that they always believe patient's pain. Nonhemodialysis nurses were found to be more sensitive in believing the patient's pain with 55.2 percent. 
A recent study found that academic physicians in the Chicago area used placebos in everyday clinical practice. ${ }^{[12]}$ Baghcheghi and Koohestani (2011) found that $23.07 \%$ of the nurses use placebo once a week on average and $63.08 \%$ use placebo once in a month on average. ${ }^{[20]}$ In this study, $21.7 \%$ of hemodialysis nurses were using placebo mostly and $77.6 \%$ of them always preferred placebo for pain management for the first step of analgesia.

In a study of Sherman and Hickner, 45\% of physicians reported administering placebos, though $96 \%$ believed that placebos had a therapeutic effect. ${ }^{[12]}$ Another study of 295 Iranian nurses, only $60(20.33 \%)$ of them believed that placebos should never be used. Most of the others considered placebo use such as permitted if the experience in the department supports its efficiency (141, or 47.76\%), or permitted if research supports its efficiency (91, or $30.84 \%){ }^{[20]}$ In this study; $86.2 \%$ of hemodialysis nurses stated that their patients report pain relief and it had a therapeutic effect in 30 minutes after saline injection. In non-hemodialysis nurses, this ratio was found 68.6 percent.

In Nitzan and Lichtenberg's study (2004), of the participants who were working as a head nurse and a physician were using placebo, 36 (68\%) of them stated that they tell the patient that he or she is receiving a real medicine, and nine of them reported that they (17\%) say nothing at all. The rest either identify the placebo as such (two, or $4 \%$ ) or tell the patient that he or she is receiving a non-specific medicine (six, or $11 \%)^{[13]}$ In another study, of the academic physicians who reported using placebos in the course of routine health care, 34\% introduced the placebo to the patient as "a substance that may help and will not hurt," 19\% said, "it is medication," $9 \%$ said, "it is medicine with no specific effect." Only $4 \%$ of the physicians explicitly said, "it is a placebo." In addition, 33\% of the physicians reported that they gave other information to patients including, "This may help you but I am not sure how it works." ${ }^{[12]}$ In this study $72 \%(\mathrm{n}=118)$ of all the nurses stated that they prefer to use a different medication name instead of saying "SF".

Physicians used placebo in a variety of circumstances. Some studies showed that placebo was used to control pain including abdominal pain. ${ }^{[12,13]}$ In this study; $74.5 \%$ of the hemodialysis nurses used placebo mostly for headache. In addition; headache was also a common reason for using placebo in nonhemodialysis nurses.

Most of the nurses in this study had used placebo for pain management. In addition, it seems that placebo usage for pain relief is very common among hemodialysis nurses and the feedback of placebo usage taken from patients is good. This may show that it would be better to try for the first step of analgesia for hemodialysis patients. Because health status of them are better known by their nurses who take care of them for three times a week.

\section{Acknowledgments}

We want to thank all nurses who contributed to this study by participating online survey system.

\section{Conflict-of-interest issues regarding the authorship or article: None declared.}

\section{Peer-rewiew: Externally peer-reviewed.}

\section{References}

1. Turk DC, Melzack R. The McGill pain questionnaire: appraisal and current status. In: Turk DC, Melzack R, editors. Handbook of pain assessment. 2nd ed. New York NY, US: Guilford Press; 2001. p. 35-52.

2. Zalon ML, Constantino RE, Andrews KL. The right to pain treatment: a reminder for nurses. Dimens Crit Care Nurs 2008;27(3):93-103.

3. Loeser JD, Melzack R. Pain: an overview. Lancet 1999;353(8):1607-9.

4. Greiner AC, Knebel E. Current educational activities in the core competencies. In: Greiner AC, Knebel E, editors. Health professions education: a bridge to quality. Washington, DC: National Academies Press; 2003. p. 75-96.

5. Francis MV. Placebo analgesia. Kerala Medical Journal 2009;2(3):120-4.

6. Nichols KJ, Galluzzi KE, Bates B, Husted BA, Leleszi JP, Simon $\mathrm{K}$, et al. AOA's position against use of placebos for pain management in end-of-life care. J Am Osteopath Assoc 2005;105:2-5.

7. Goodwin JS, Goodwin JM, Vogel AV. Knowledge and use of placebos by house officers and nurses. Ann Intern Med 1979;91(1):106-10.

8. Amanzio M, Benedetti F. Neuropharmacological dissection of placebo analgesia: expectation-activated opioid systems versus conditioning-activated specific subsystems. J Neurosci 1999;19(1):484-94.

9. McCaffery M, Arnstein P. The debate over placebos in pain management. The ASPMN disagrees with a recent placebo position statement. Am J Nurs 2006;106(2):62-5.

10. Levine JD, Gordon NC, Smith R, Fields HL. Analgesic respons- 
es to morphine and placebo in individuals with postoperative pain. Pain 1981;10(3):379-89.

11. Hróbjartsson A, Norup M. The use of placebo interventions in medical practice-a national questionnaire survey of Danish clinicians. Eval Health Prof 2003;26(2):153-65.

12. Sherman R, Hickner J. Academic physicians use placebos in clinical practice and believe in the mind-body connection. $J$ Gen Intern Med 2008;23(1):7-10.

13. Nitzan U, Lichtenberg P. Questionnaire survey on use of placebo. BMJ 2004;329(7472):944-6.

14. Berger JT. Placebo medication use in patient care: a survey of medical interns. West J Med 1999;170(2):93-6.

15. Ernst $E$, Abbot NC. Placebos in clinical practice: results of a survey of nurses. Perfusion 1997;10(4):128-30.

16. Gray G, Flynn P. A survey of placebo use in a general hospital. Gen Hosp Psychiatry 1981;3(3):199-203.

17. HOFLING CK. The place of placebos in medical practice. GP 1955;11(6):103-7.

18. Krivo S, Reidenberg MM. Assessment of patients' pain. N Engl J Med 1996;334(1):59.

19. Field L. Factors influencing nurses' analgesia decisions. Br J Nurs 1996;5(14):838-44.

20. Baghcheghi $N$, Koohestani HR. Placebo use in clinical practice by nurses in an Iranian teaching hospital. Nurs Ethics 2011;18(3):364-73. 